\title{
Morphological characterization of fruit, seed and seedling and germination of Hymenaea courbaril L. (Fabaceae) ('Jatobá') ${ }^{1}$
}

\author{
Manoela Mendes Duarte ${ }^{2 *}$, Sheilly Raquelly Prado de Paula ${ }^{2}$, \\ Flaick Rodrigo de Lima Ferreira ${ }^{2}$, Antonio Carlos Nogueira ${ }^{2}$
}

\begin{abstract}
This study has aimed to characterize the morphology of fruit, seed and seedling and evaluate the germination of Hymenaea courbaril L., under different substrates and temperatures. The physical characteristics were determined, as well as the morphological description of the internal and external parts of fruits and seeds, stages of germination and early seedling development. Germination tests were conducted in a completely randomized design, in a $3 \times 2$ factorial scheme, with three temperatures $\left(20^{\circ} \mathrm{C}, 25^{\circ} \mathrm{C}\right.$ and $30^{\circ} \mathrm{C}$ ) and two substrates (sand and vermiculite), with six plots of 30 seeds. The germination percentage, germination speed index (GSI) and mean germination time (MGT) were calculated. The fruits are dry and woody and the seeds are exalbuminous, with an axial embryo. The germination is epigeal and the seedling is phanerocotylar. The combination of vermiculite or sand associated to temperatures of $25^{\circ} \mathrm{C}$ or $30{ }^{\circ} \mathrm{C}$ is effective for conducting the germination tests.
\end{abstract}

Index terms: Hymenaea courbaril, temperature, substrate, biometrics of seeds.

\section{Caracterização morfológica do fruto, semente e plântula e germinação de Hymenaea courbaril L. (Fabaceae) ('Jatobá')}

\begin{abstract}
RESUMO - O presente trabalho teve como objetivo caracterizar a morfologia do fruto, semente e plântula e avaliar a germinação de Hymenaea courbaril L., submetida a diferentes substratos e temperaturas. Foram determinadas as características físicas, além da descrição morfológica interna e externa dos frutos e sementes, fases da germinação e desenvolvimento inicial da plântula. Os testes de germinação foram executados em delineamento inteiramente casualizado, em esquema fatorial $3 \times 2$, sendo três temperaturas $\left(20^{\circ} \mathrm{C}, 25{ }^{\circ} \mathrm{C}\right.$ e $\left.30{ }^{\circ} \mathrm{C}\right)$ e dois substratos (areia e vermiculita), com seis repetições de 30 sementes. Foram determinados a porcentagem de germinação, o índice de velocidade de germinação e tempo médio de germinação. Os frutos são secos e lenhosos e as sementes são exalbuminosas, com embrião axial. A germinação é epígea e a plântula fanerocotiledonar. A combinação dos substratos vermiculita ou areia quando aliados às temperaturas de $25^{\circ} \mathrm{C}$ ou $30{ }^{\circ} \mathrm{C}$ são eficientes para condução dos testes de germinação.
\end{abstract}

Termos para indexação: Hymenaea courbaril, temperatura, substrato, biometria de sementes.

\section{Introduction}

Hymenaea courbaril L. (Fabaceae - Caesalpinioideae) known as "Jatobá", is a native species, semi-deciduous, belonging to the group of late or climax secondary ones (Carvalho, 2003; Lorenzi, 2008). It shows wide distribution in South America and Central America, from Mexico to Paraguay, occurring in a dispersed form in upland forests and certain high plains, more frequently in clayey and poor soils (Shanley, 2005). Despite its wide distribution in the Brazilian territory, found from the state of Piauí to northern Paraná, in the Semi-deciduous Seasonal Forest (Lorenzi, 2008) the species is considered rare, occurring naturally in low densities, usually from one to six individuals per hectare (Carvalho, 2003).

The mature tree is $15-20 \mathrm{~m}$ tall and the trunk can reach up to $1 \mathrm{~m}$ in diameter at breast height. Its wood is considered valuable due to the high density and satisfactory resistance to attack by wood-destroying organisms and is used in folk medicine, in construction, in the composition of heterogeneous plantations and for afforestation of parks and large gardens (Carvalho, 2003; Lorenzi, 2008). The fruit is an indehiscent legume and its seed is surrounded by an edible yellowish powder (Busatto et al., 2013), of important food value for rural communities and for wildlife (Lorenzi, 2008). The seeds are classified as orthodox

${ }^{1}$ Submitted on 02/12/2016. Accepted for publication on 05/24/2016.

${ }^{2}$ Setor de Ciências Agrárias, Universidade Federal do Paraná, 80210-170 - Curitiba, PR, Brasil.

*Corresponding author: <manu-florestal@hotmail.com> 
or intermediate (Melo and Mendes, 2005), presenting cutaneous numbness (Almeida et al., 1999), a factor that ensures longevity of the seeds, allowing them to germinate even after long periods of dispersion or storage.

Knowledge of the morphological structures of forest species is of great importance to many studies related to forestry. Morphological studies of fruits, seeds, seedlings and saplings are shown to be essential for the recognition of the species in the natural environment, recovery studies of degraded areas and cataloging of species, allowing a quick and secure identification in the field (Barretto and Ferreira, 2011). Some studies have been conducted in order to characterize the morphology and assist in the taxonomic identification of native species, such as the work done by Gogosz et al. (2015), Duarte et al. (2015), Bassaco et al. (2014), Halinski et al. (2013) and Rego et al. (2011). Also, the use of morphological characters contributes to ecological studies related to the knowledge of the species autoecology, dispersal mechanisms, ecological succession and natural regeneration, as can be seen in the work developed by Ressel et al. (2004), Alves et al. (2013) and Gogosz et al. (2015).

In addition to obtaining grants for dispersion studies and seedling establishment in native forests, the biometry of fruits and seeds can be used in breeding programs, because, according to Macedo et al. (2009) and Gonçalves et al. (2013), biometric characters allow differentiation of species of the same genus, identification of genetic variability within populations of the same species, and analysis of the relationship between this variability and environmental factors.

In addition to the morphological and biometrical characteristics, the importance of studies related to potential germination of the seeds should be highlighted, which are usually determined by laboratory tests, carried out under controlled conditions (Duarte et al., 2015). Germination test is the most widely used method for determining seeds quality in a given lot and allows the evaluation of the viability under favorable conditions (Oliveira et al., 2008), and the temperature and the substrate are the main laboratory factors that control germination (Bassaco et al., 2014).

In general, seeds have variable germination performance when subjected to different temperatures and substrates, and the knowledge of the responses of the germination process from each species regarding these factors is of fundamental importance (Mondo et al., 2008). Regarding temperature, there is no determination of a good and uniform value for all species, and the range from 20 to $30{ }^{\circ} \mathrm{C}$ proves to be suitable for the germination of many forest species (Marcos-Filho, 2005).

The substrate directly influences the germination, due to its structure, aeration, water holding capacity and degree of infestation of pathogens, which may favor or hinder the seeds germination process (Guedes et al., 2010). According to the Regras para Análise de Sementes [R.A.S. (Rules for Seed Testing)] (Brasil, 2009a), the most widely used substrates for the germination test are paper and sand. Also, although vermiculite is not mentioned in the R.A.S., it has been used with good results for forest species due to low contamination of microorganisms, good absorption capacity and water retention, promoting good aeration and allowing the proper development of the seedlings (Lima Junior, 2010).

Given the above, the aim of this study was to characterize the morphology of the fruit, seed and seedling and evaluate the germination of $H$. courbaril submitted to different substrates and temperatures.

\section{Material and Methods}

Fruit collection was carried out in the period from December 2014 to January 2015 in fragments remaining from the Semideciduous Seasonal Forest located in the Brazilian municipalities of Assis (22 $39^{\prime} 42^{\prime \prime} \mathrm{S}$ and $\left.50^{\circ} 24^{\prime} 44^{\prime \prime} \mathrm{W}\right)$, Quatá $\left(22^{\circ} 14^{\prime} 51^{\prime \prime} \mathrm{S}\right.$

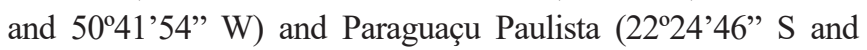
$50^{\circ} 34^{\prime} 33^{\prime \prime} \mathrm{W}$ ), in the state of São Paulo. A total of 11 parent trees was selected, these being spaced apart at least 300 meters.

The fruits were collected directly from the soil, being selected only those which had no visible injuries. The fruits were manually opened with the aid of a knife and the seeds were separated from the farinaceous pulp by manual maceration. Then the seeds were placed in plastic bags and sent to the Laboratory of Forest Seeds at Federal University of Paraná, located in the municipality of Curitiba, PR, where the other stages of the experiments were performed. Besides, a sample of the plant material was collected, identified and the exsiccated specimen was listed in the Forest School Herbarium under number EFC14517.

\section{Physical and biometrical analyses of the seeds}

For physical characterization of the lot, consisting of the seeds obtained from all the parent trees, moisture content was determined in two replications of 10 seeds from the greenhouse method at $105{ }^{\circ} \mathrm{C} \pm 3{ }^{\circ} \mathrm{C}$ for 24 hours, and the thousand seed weight (TSW) was obtained, using eight replications of 100 seeds, weighed in an analytical balance with an accuracy of $0.0001 \mathrm{~g}$, according to the methodologies described in the Regras para Análise de Sementes (Brasil, 2009a). Based on this, the number of seeds per kilogram and the dry biomass of 1000 seeds were also determined.

For the biometric characterization, 60 seeds were used, randomly taken from the sample. With the aid of a caliper, 
the length, width and thickness were measured. Length was measured from the base to the apex, and the width and thickness were measured on the midline of the seeds. The weight of each seed was also determined in an analytical balance with an accuracy of $0.0001 \mathrm{~g}$.

\section{Morphological characterization of the fruit, seed and seedling}

For a description and illustration of the fruits and seeds, 50 units of each structure were used, randomly taken from the sample. The fruits were described in: fruit type, dehiscence, characteristics of the epicarp (texture, color), mesocarp (consistency and color) and endocarp (consistency and color).

The seeds were described in the external and internal aspects. External observed aspects were: color, texture, consistency and integument color, hilum position, micropyle and raphe. To study the internal morphology, the seeds were hydrated in distilled water and from transverse and longitudinal sections made with a scalpel blade the following characteristics were illustrated and described: presence or absence of endosperm, embryo type and color, and shape of the embryonic axis.

To characterize the seedling and stages of germination, 50 seeds were germinated in plastic trays containing vermiculite substrate and kept in germination chambers at a temperature of $25{ }^{\circ} \mathrm{C}$ under constant white light. Observations of the development were carried out daily after the onset of the germination, and they were considered seedlings when the protophilus were already completely formed. In this stage, the following vegetative elements were described and illustrated: type of germination, root, neck, hypocotyl, epicotyl, cotyledons and protophilus. Seedlings were observed in various stages, from 5 to 28 days after germination.

The observations were made with the aid of a table stereoscopic microscope and at the naked eye. The illustrations were done manually and the nomenclatures used to describe fruits, seeds and seedlings of $H$. courbaril were based in the Illustrated Glossary of Morphology (Brasil, 2009b).

\section{Germination at different temperatures and substrates}

As a pre-germination treatment, all the seeds were sterilized with a sodium hypochlorite solution ( $2.5 \%$ active chlorine) for five minutes. To overcome dormancy, the seeds were laterally sanded with the aid of a grinding wheel and placed in distilled water to soak for a period of 24 hours, according to the methodology suggested for the species by Souza et al. (2013).

To evaluate the effect of temperature and substrate on germination, the experiment followed the premise of a completely randomized design. Therefore, a $3 \times 2$ factorial arrangement was adopted, organized in three temperatures $\left(20{ }^{\circ} \mathrm{C}, 25{ }^{\circ} \mathrm{C}\right.$ and $30{ }^{\circ} \mathrm{C}$ ) and on two substrates (sand and vermiculite) with six replications of 30 seeds for each treatment, placed on plastic trays $(29 \times 20 \mathrm{~cm})$ covered by plastic wrap previously sterilized with alcohol $70 \%$ and allocated in a Biochemical Oxygen Demand (B.O.D.) type germinator, under constant light.

Sand substrate was standardized at a $0.8-\mathrm{mm}$ mesh sieve, washed and sterilized in an oven at $200{ }^{\circ} \mathrm{C}$ for two hours, 800 grams were used for each tray, wetted with $170 \mathrm{~mL}$ of distilled water $(60 \%$ of retention capacity). For the vermiculite substrate, $100 \mathrm{~g}$ were used in each tray, together with $240 \mathrm{~mL}$ of distilled water. Water replenishment was held whenever necessary.

Assessments occurred daily, started on the first day after the installation of the experiment and continued for three consecutive days until germination was stabilized. The germination criterion adopted was the primary root protrusion, approximately $3 \mathrm{~mm}$ in length. After the closure of the experiments, the seeds that did not germinate were classified as hard seeds and seeds attacked by fungi.

Germination percentage, germination speed index (Maguire, 1962) and mean germination time (MGT) (Laboriau, 1983) were calculated. The data were submitted to the Bartlett's test to check the homogeneity, and afterwards to the analysis of variance. When a significant difference was observed, comparison of means was performed by the Tukey's test at a $5 \%$ level of probability.

\section{Results and Discussion}

\section{Physical and biometrical analyses of the seeds}

The lot of seeds of $H$. courbaril presented thousand seed weight (TSW) equal to $3,102 \mathrm{~g}(\mathrm{CV}=4.69 \%)$, and a number of seeds per kilogram of 322 . At the time of analysis, the seeds had $13.1 \%$ moisture, resulting in a dry biomass of a thousand seeds equal to $336 \mathrm{~g}$.

The values observed are close to the ones mentioned by Melo and Mendes (2005), who state that the moisture content of the species varies from 9 to $12 \%$, and that, on average, one kilogram of seeds may contain from 166 to 500 units, with a thousand seed weight (TSW) between 4 and 5 kilograms (Kg). Cruz et al. (2001) have observed that for Hymenaea intermedia Ducke, species of the same genus, the average weight of 100 seeds was $371.3 \mathrm{~g}$, resulting in about 270 seeds per kilogram.

As for its biometrics, the seeds of $H$. courbaril had an average length of $22.6 \mathrm{~mm}$, average width of $17.7 \mathrm{~mm}$, average thickness of $12.1 \mathrm{~mm}$ and an average weigh of 3.4 g (Table 1). Similar values were described by Andrade et al. (2010) and Almeida et al. (2011) for H. courbaril, by Botelho et al. (2000) for Hymenaea stigonocarpa Mart.ex and Hayne and Cruz et al. (2001) for H. intermedia. 
Table 1. Length, width, thickness and weight of seeds of Hymenaea courbaril.

\begin{tabular}{cccccc}
\hline Dimensions $(\mathrm{mm})$ & Minimum & Average & Maximum & Standard deviation & Coefficient of variation (\%) \\
\hline Length & 17.5 & 22.6 & 28.0 & 2.23 & 9.9 \\
Width & 12.6 & 17.7 & 22.7 & 2.45 & 13.8 \\
Thickness & 6.9 & 12.1 & 15.8 & 2.17 & 17.9 \\
Weight $(\mathrm{g})$ & 1.6668 & 3.4416 & 5.5168 & 1.02 & 29.7 \\
\hline
\end{tabular}

\section{Morphological characterization of the fruit, seed and seedling}

The fruit of $H$. courbaril is of a dry vegetable, woody and indehiscent type; elongated polyspermy, rounded or slightly obtuse apex, rounded base and full edge; edges of thick and welded valves surrounding all the fruit
(Figure 1 - A). It features a thin dark brown epicarp, characteristically shiny (polished appearance), rough texture with light brown points. The mesocarp is thicker, stringy, hard, light brown and contains a lot of resin. The endocarp is thin, with soft and spongy texture.

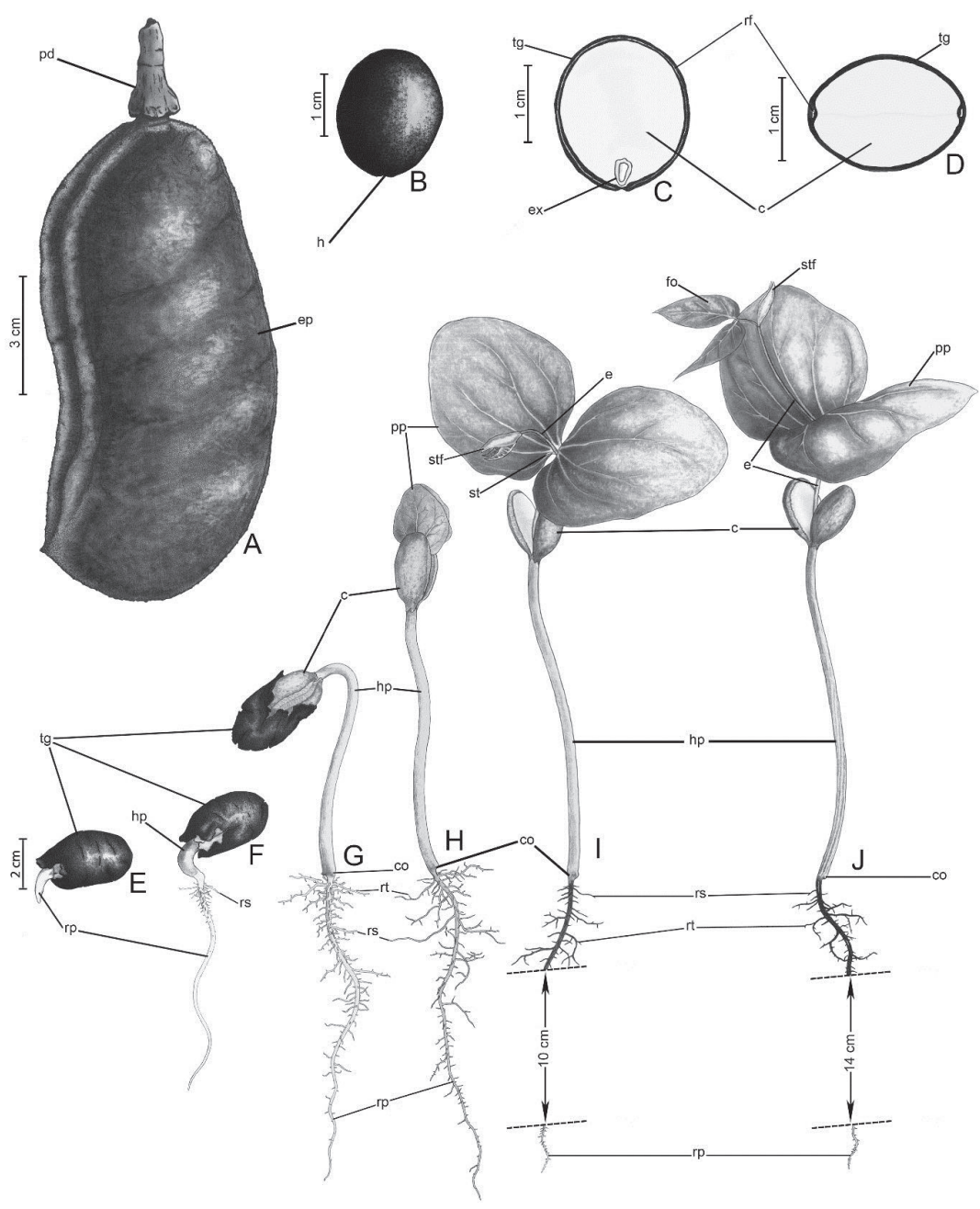

Figure 1. Fruit, seed, germination states and seedlings of Hymenaea courbaril: A - fruit; B - seed; C - seed in a longitudinal section showing the embryonic axis; D - cross-sectional seed; $\mathrm{E}-\mathrm{G}$ - stages of the germination; $\mathrm{H}$ - J - development of seedlings; $\mathrm{pd}$ - peduncle; ep - epicarp; $\mathrm{h}$ - hilum; tg - integument; $\mathrm{rf}$ - raphe; c - cotyledons; ex - embryonic axis; $\mathrm{rp}$ - primary root; hp - hypocotyl; tg - integument; rs - secondary root; co - neck; pp - protophilus; rt - tertiary root; ep - epicotyl; st - stipule; stf - leaf stipule; fo - foliole. Note: the scale is the same from E to J; view of the cutting in the roots of $\mathrm{I}$ and $\mathrm{J}$ represented in real magnitude $(\mathrm{cm})$. 
The seeds of $H$. courbaril are covered by a fibrous yellowish layer, forming a chalky pulp, with a characteristic odor. Barroso et al. (1999) mention that the seeds of Hymenaea sp. are surrounded by white aril that, at a later stage of development, begins to crumble in a dry floury mass, pink-brownish and with a penetrating odor. Botelho et al. (2000) have also described the presence of greenish-yellow aril, that is soft, fibrous-floury and with a characteristic odor for Hymenaea stignocarpa Mart.ex Hayne.

The presence of the floury aril observed in the fruit is a characteristic of plants with a zoochorous dispersion, such as H. courbaril (Ressel et al., 2004). These species have fruits and/or seeds with different morphological and organoleptic characteristics that encourage and facilitate its consumption by animals, and potentially the dispersion of its seeds (Barroso et al., 1999; Gogosz et al., 2015).

The seeds have an ovoid to globular shape, which may be slightly flattened; integument of stony consistency, reddishbrown to dark brown, with smooth and opaque appearance; hilum with an oblong shape, small, located in the basal area and inconspicuous micropyle (Figure 1-B).

The seeds do not present endosperm, being, therefore, exalbuminous; the embryo is axial, yellow-greenish and ovoid to globular shape; the cotyledons are thick, fleshy, with jagged edges, and have a groove in the suture line; short and cylindrical embryonal axis; raphe internal to the integument, surrounding it completely by the suture line of the cotyledons (Figure $1-\mathrm{C}$ and $\mathrm{D}$ ).

The germination of the seeds of $H$. courbaril is epigeous and the seedling is phanerocotylar, beginning on the $3^{\text {rd }}$ day and extending to the $18^{\text {th }}$ day. In the beginning of the germination process ( $3^{\text {rd }}$ day), the primary root emission takes place, which is cylindrical, curved and yellow-whitish. As there is the development of the primary root, thickening of the hypocotyl is observed, which is cylindrical and initially curved, reddishbrown with mild dilatation of the neck, and the presence of simple trichomes, scattered and dispersed throughout its length ( Figure $1-\mathrm{E}$ and F). Likewise, Botelho et al. (2000) have also observed for $H$. stignocarpa the presence of simple trichomes, short and thin in the area of the hypocotyl.

Six days after the onset of the germination, primary roots showed as approximately $7 \mathrm{~cm}$ long, starting the rise of the first secondary roots. Initially, both the primary and the secondary roots are winding, cylindrical and tender, appearing yellowish and gradually turning into a rusty color (Figure 1-F).

From the $15^{\text {th }}$ day after germination, the hypocotyl is already quite elongated, approximately $11 \mathrm{~cm}$ and green-reddish, at which time the cotyledons, slightly pinkish, initiate the opening process for subsequent release of the first couple of protophilus
(Figure 1-G). Concomitant with the opening of the cotyledons, which are sessile, hairless and fleshy, there is the detachment of the integument because of the epicotyl and protophilus structures generally forcing the integument down (Figure $1-\mathrm{G}$ and $\mathrm{H}$ ). According to Kodama and Sartori (2007) the cotyledons of $H$. courbaril are elliptical, without the presence of trichomes and have green-reddish color.

Many morphological features presented by the seedlings are directly related to their development and initial establishment in a natural environment (Ressel et al.,2004). Gogosz et al. (2015) have observed in their study that late secondary species have no trichomes in the cotyledons, and these are presented much thicker than those observed in pioneer species, results that corroborate those observed for $H$. courbaril in the present study.

The ovoid protophilus with stipules and an expressive primary veining, with a rounded apex and a full edge, are initially green-reddish, turning to a waxy dark green when the seedling is completely formed. Kodama and Sartori (2007) describe cordiform protophilus occurring in H. stigonocarpa Hayne var. brevipetiolata N. Mattos, while wide ovoid ones are observed in the typical range (H. stignocarpa) and similarly to that in the present work, they have observed in ovoid protophilus in H. courbaril.

From this stage, the cylindrical, sub-herbaceous and light green epicotyl lengthens, releasing between the $20^{\text {th }}$ and $25^{\text {th }}$ days the first couple of metaphylls that arise among welldeveloped foliaceous stipules (Figure $1-\mathrm{J}$ ). According to Melo and Mendes (2005), the metaphylls are bifolioles with alternate arrangements: elliptical-falcate folioles, with an oblique base, acuminate apex, whole margin and light green.

After 28 days, the seedlings already well formed have a long taproot, which is winding, cylindrical, dark brown, woody and approximately $14 \mathrm{~cm}$ long. In this stage, the seedlings are approximately $14 \mathrm{~cm}$ long for the hypocotyl and $10 \mathrm{~cm}$ long for the epicotyl and are in transition to the phase of sapling (Figure 1 $-\mathrm{J}$ ).

\section{Seeds germination at different temperatures and substrates}

The average germination of $H$. courbaril was $75 \%$, being lower than the values verified by Cruz et al. (2001) and Gomes et al. (2013) and higher than the ones mentioned by Carvalho et al. (2005), all for seeds of the same species and that have undergone the mechanical chiseling process. In general, the treatment of overcoming dormancy used in this study showed satisfactory results for germination; however, Carpanezzi and Marques (1981) mention that the use of sulfuric acid in the process can provide germination of up to $90 \%$ of the species.

In general, from the seeds that did not germinate, 
93\% were classified as hard. There were no further analyses, but it is assumed that no germination occurred due to more superficial chiseling, hampering the seed imbibition process. Also, $7 \%$ of the non-germinated seeds were classified by the presence of fungi. This value may be considered low when compared to the one mentioned by Carvalho et al. (2005), who have attributed the low percentage of germination of $\mathrm{H}$. courbaril to the high proliferation of fungi observed in their experiment.

The data resulting from the analysis of variance for the sources of variation temperature and substrate on seed germination of $H$. courbaril are shown in Table 2. As it is possible to observe, there was an interaction among the factors for all the variables analyzed.

Regarding the germination percentage, the combination of vermiculite and $30{ }^{\circ} \mathrm{C}$ provided a higher germination rate $(95 \%)$, followed by the combination of sand and $30{ }^{\circ} \mathrm{C}$ $(89 \%)$. Both the substrate sand as vermiculite combined with the temperature of $25{ }^{\circ} \mathrm{C}$ have also shown above average germination. The lowest percentage of germination occurred in the combination of sand and $20{ }^{\circ} \mathrm{C}(31 \%)$, statistically differing from the other treatments (Table 3 ).

Table 2. Analysis of variance for germination $(\mathrm{G})$ percentage, germination speed index (GSI) and mean germination time (MGT) of seeds of Hymenaea courbaril in different temperatures and substrates.

\begin{tabular}{ccccc}
\hline \multirow{2}{*}{ Source of variation } & \multirow{2}{*}{ D. F. } & \multicolumn{3}{c}{ Mean Square ${ }^{(1)}$} \\
\cline { 3 - 5 } & 2 & G & GSI & MGT \\
\hline Temperature & 1 & $2669.44^{* *}$ & $3.45^{* *}$ & $16.56^{* *}$ \\
Substrate & 2 & $6145.37^{* *}$ & $17.60^{* *}$ & $47.74^{* *}$ \\
Temperature x Substrate & - & $908.33^{*}$ & $1.55^{* *}$ & $13.15^{* *}$ \\
Average & - & 74.72 & 2.56 & 10.32 \\
Coefficient of variation (\%) & 18.26 & 19.59 & 11.48 \\
\hline
\end{tabular}

(1) * significant at $\alpha<0.05 ;{ }^{* *}$ significant at $\alpha<0.01$; ${ }^{\text {ns }}$ nonsignificant; D.F: Degrees of freedom.

Table 3. Germination $(\mathrm{G})$ percentage, germination speed index (GSI), and mean germination time (MGT) of seeds of Hymenaea courbaril in different temperatures and substrates. ${ }^{(1)}$

\begin{tabular}{ccc}
\hline \multirow{2}{*}{ Temperature $\left({ }^{\circ} \mathrm{C}\right)$} & \multicolumn{2}{c}{ Substrate } \\
\cline { 2 - 3 } & \multicolumn{3}{c}{ Sand } & Germiculite \\
\hline 20 & $30.56 \mathrm{bB}$ & $67.78 \mathrm{aB}$ \\
25 & $78.33 \mathrm{aA}$ & $87.22 \mathrm{aA}$ \\
30 & $89.44 \mathrm{aA}$ & $95.00 \mathrm{aA}$ \\
\hline \multicolumn{3}{c}{ GSI } \\
\hline 20 & $0.78 \mathrm{bC}$ & $1.83 \mathrm{aB}$ \\
25 & $2.14 \mathrm{bB}$ & $3.17 \mathrm{aA}$ \\
30 & $3.83 \mathrm{aA}$ & $3.62 \mathrm{aA}$ \\
\hline \multicolumn{2}{c}{ MGT (days) } \\
\hline 20 & $12.74 \mathrm{aA}$ & $11.31 \mathrm{bA}$ \\
30 & $12.50 \mathrm{aA}$ & $9.09 \mathrm{bB}$ \\
\hline & $7.74 \mathrm{aB}$ & $8.51 \mathrm{aB}$ \\
\hline
\end{tabular}

${ }^{(1)}$ Means followed by equal lowercase letters in the column and uppercase letters in the row do not differ at the level of $5 \%$ of probability by the Tukey's test.

The literature shows that there is wide divergence among the best conditions for forest species to express their germination potential. Lima et al. (2006) have observed that the germination percentage for seeds of Caesalpinia ferrea Mart. ex Tul. was influenced by the temperature, but not by the substrates used. In contrast, Bassaco et al. (2014) have observed an interaction between temperature and substrate, recommending the use of the combination between vermiculite and $30{ }^{\circ} \mathrm{C}$ for the germination of Sebastiania brasiliensis (Spreng.). These results indicate that each species shows a differentiated behavior of germination when subjected to the same conditions. Therefore, tests are necessary to know the specific demands of each species.

The combination of sand and $30^{\circ} \mathrm{C}$ proved to be superior for the germination speed index (3.83), followed by the combination of vermiculite and $30{ }^{\circ} \mathrm{C}(3.62)$, both not statistically different from each other. Conversely, the combination that showed the lowest value for the GSI was sand and $20{ }^{\circ} \mathrm{C}$, significantly different from the other treatments (Table 3 ). The combination between vermiculite and the temperature of $25^{\circ} \mathrm{C}$ has also shown satisfactory results (3.17).

It is also noteworthy that, regardless of the substrate, the combination with higher temperatures gave higher GSI (Table 3). These observations have been made by Nascimento (2000), who states that, in general, low temperatures reduce, while high temperatures increase, the germination rate, and this change can also affect the final percentage of germination.

When analyzing GSI in seeds of Parapiptadenia rigida (Benth.) Brenan, Mondo et al. (2008) observed interaction 
among factors, indicating that the combination of vermiculite and $25{ }^{\circ} \mathrm{C}$ showed the best results. The interaction between vermiculite and $30{ }^{\circ} \mathrm{C}$ has also shown to be higher for the GSI of seeds of $S$. brasiliensis (Bassaco et al., 2014). The efficiency of the vermiculite substrate has been observed for various forest species, mainly due to its good water absorption and retention capacity (Lima Junior, 2010).

The best results for the variable mean germination time (MGT) are related to the lowest rates observed, i.e., the smaller the value of MGT, the more efficient the treatment was. Thus, in this study it was found that the combination of sand and $30{ }^{\circ} \mathrm{C}$, followed by vermiculite and $30^{\circ} \mathrm{C}$, showed better results ( 7.74 and 8.51 days, respectively). In contrast, the combination of sand and $20^{\circ} \mathrm{C}$ and sand and $25^{\circ} \mathrm{C}$ proved to be less efficient, with the highest values for MGT (Table 3).

When analyzing the germination of Casearia decandra Jacq. in different substrates and temperatures, Halinski et al. (2013) also observed an interaction among these factors, suggesting that the paper roll substrate and temperature of $30^{\circ} \mathrm{C}$, followed by vermiculite at $30^{\circ} \mathrm{C}$, also showed the best results. Cruz et al. (2001) have observed for $H$. intermedia a mean germination time (MGT) of 18.9 days for chiseled seeds and 68.6 days for seeds that have not undergone the treatment of overcoming dormancy.

\section{Conclusions}

The fruit of Hymenaea courbaril is the dry legume type and indehiscent; the seed is exalbuminous with an axial embryo and thick cotyledons; germination is epigeous and the seedling is phanerocotylar, starting on the $3^{\text {rd }}$ day and extendingto the $18^{\text {th }}$ day. The combination of vermiculite or sand with temperatures of $25^{\circ} \mathrm{C}$ or $30^{\circ} \mathrm{C}$ is effective for the germination of seeds of $H$. courbaril.

\section{References}

ALMEIDA, M.B.; SOUZA, W.C.O.; GOMES, E.C.S.; VILLAR, F.C.R. Descrição morfológica do fruto e semente do jatobá (Hymenaea courbaril L.). Revista Semiárido de Visu, v.1, n.2, p.107-115, 2011. http://periodicos. ifsertao-pe.edu.br/ojs2/index.php/revista/article/view/39

ALMEIDA, M.J.B.; FERRAZ, I.D.K.; BASSINI, F. Estudos sobre a permeabilidade do tegumento e a germinação de sementes de Hymenaea courbaril L. Caesalpinoideae), uma espécie de uso múltiplo. Revista da Universidade do Amazonas: Série Ciências Agrárias, v.8, n.1-2, p.63-71, 1999.

ALVES, M.C.J.L.; LIMA, P.B.; LIMA, L.F.; ZICKEL, C.S. Descrição morfológica para identificação das plântulas de nove espécies lenhosas de uma floresta de restinga. Biota Neotropica, v.13, n.3, p.374-383, 2013. http:// www.scielo.br/pdf/bn/v13n3/1676-0603-bn-13-03-374.pdf
ANDRADE, L.A.; BRUNO, R.D.L.A.; LUCENA, R.; OLIVEIRA, L.S.B.; SILVA, H.T.F. Aspectos biométricos de frutos e sementes, grau de umidade e superação de dormência de jatobá. Acta Scientiarum Agronomy, v.32, n.2, p.293-299, 2010. http://www.scielo.br/pdf/asagr/v32n2/a16v32n2.pdf

BARRETTO, S.S.B.; FERREIRA, R.A. Aspectos morfológicos de frutos, sementes, plântulas e mudas de Leguminosae mimosoideae: Anadenanthera colubrina (Vellozo) Brenan e Enterolobium contortisiliquum (Vellozo) Morong. Revista Brasileira de Sementes, v.33, n.2, p.223-232, 2011. http:// www.scielo.br/pdf/rbs/v33n2/04.pdf

BARROSO, G. M.; MORIM, M. P.; PEIXOTO, A. L.; ICHASO, C. L. F. Frutos e sementes: morfologia aplicada à sistemática de dicotiledôneas. Viçosa: UFV, 1999. 443 p.

BASSACO, M.V.M.; NOGUEIRA, A.C.; COSMO, N.L. Avaliação da germinação em diferentes temperaturas e substratos e morfologia do fruto, semente e plântula de Sebastiania brasiliensis. Revista Floresta, v.44, n.3, p.381-392, 2014. http://ojs.c3sl.ufpr.br/ojs/index.php/floresta/article/ view/32076/23187

BOTELHO, S.A.; FERREIRA, R.A.; MALAVASI, M.M.; DAVIDE, A.C. Aspectos morfológicos de frutos, sementes, plântulas e mudas de jatobádo-cerrado (Hymenaea stigonocarpa Mart. ex Hayne)-Fabaceae. Revista Brasileira de Sementes, v.22, n.1, p.144-152, 2000. http://www.abrates.org. br/revista/artigos/2000/v22n1/artigo20.pdf

BRASIL. Ministério da Agricultura, Pecuária e Abastecimento. Regras para análise de sementes. Ministério da Agricultura, Pecuária e Abastecimento. Secretaria de Defesa Agropecuária. Brasília: MAPA/ACS, 2009a. 395p. http:// www.agricultura.gov.br/arq_editor/file/2946_regras_analise_sementes.pdf

BRASIL. Ministério da Agricultura, Pecuária e Abastecimento. Glossário ilustrado de morfologia. Brasília: Mapa/ACS, 2009b. 406p. http://www. agricultura.gov.br/arq_editor/file/10829_glossario_ilustrado_morfologia-2.pdf

BUSATTO, P.C.; NUNES, A.S.; COLMAN, B.A.; MASSON, G.L. Superação de dormência em sementes de jatobá (Hymenaea courbaril L.). Revista Verde, v.8, n.1, p.154-160, 2013. http://www.gvaa.com.br/revista/ index.php/RVADS/article/view/1807/1524

CARPANEZZI, A.A.; MARQUES, L.C.T. Germinação de sementes de jutai-açu (Hymenaea courbaril L.) e de jutai-mirim (H. parvifolia Huber) escarificadas com ácido sulfúrico comercial. Belém: Embrapa Amazônia Oriental, 1981. 15p. (Circular Técnica, 19). http://ainfo.cnptia.embrapa.br/ digital/bitstream/item/33541/1/CPATU-CirTec19-2.pdf

CARVALHO, P.S.; MIRANDA, S.C.; SANTOS, M.L. Germinação e dados biométricos de Hymenaea stigonocarpa Mart. Ex Hayne (LeguminosaeCaesalpinoideae)-Jatobá-do-Cerrado. Revista Anhanguera, v.6, n.1, p.101-116, 2005. http://pos.anhanguera.edu.br/wp-content/uploads/2015/07/cap_05_2005.pdf

CARVALHO, P.E.R. Espécies arbóreas brasileiras. Brasília: Embrapa Informação Tecnológica; Colombo, Embrapa Florestas, v.1, 2003. 1039 p.

CRUZ, E.D.; MARTINS, F.O.; CARVALHO, J.E.U. Biometria de frutos e sementes e germinação de jatobá-curuba (Hymenaea intermedia Ducke, Leguminosae - Caesalpinioideae). Revista Brasílica Botânica, v.24, n.2, p.161-165, 2001. http://www.scielo.br/pdf/rbb/v24n2/a05v24n2.pdf

DUARTE, M.M.; MILANI, J.E.F.; BLUM, C.T.; NOGUEIRA, A.C. Germinação e morfologia de sementes e plântulas de Albizia edwallii (Hoehne) Barneby \& J. W. Grimes. Revista Caatinga, v.28, n.3, p.166-173, 2015. http:// periodicos.ufersa.edu.br/revistas/index.php/sistema/article/view/4529/pdf 288 
GOGOSZ, A.M.; BOEGER, M.R.T.; COSMO, N.L.; NOGUEIRA, A.C. Morfologia de diásporos e plântulas de espécies arbóreas da floresta com araucária, no sul do Brasil. Floresta, v.45, n.4, p.819-832, 2015. http://ojs. c3sl.ufpr.br/ojs/index.php/floresta/ article/view/35017/27442

GOMES, M.B.; FARIA, A.A.; CERQUEIRA, D.S.; BAILÃO, L.L. Avaliação de métodos para a superação de dormência de sementes de jatobá (Hymenaea courbaril L.). Revista Eletrônica Interdisciplinar, v.1, n.9, p.6-9, 2013. http://revista.univar.edu.br/index.php/interdisciplinar/article/view/45

GONÇALVES, L.G.V.; ANDRADE, F.R.; MARIMON JUNIOR, B.H.; SCHOSSLER, T.R.; LENZA, E.; MARIMON, B.S. Biometria de frutos e sementes de mangaba (Hancronia speciosa Gomes) em vegetação natural na região de Mato Grosso, Brasil. Revista de Ciências Agrárias, v.36, n.1, p.3140, 2013. http://www.scielo.mec.pt/pdf/rca/v36n1/v36n1a06.pdf

GUEDES, R.S.; ALVES, E.U.; GONÇALVES, E.P.; BRAGA JÚNIOR, J.M.; VIANA, J.S.; COLARES, P.N.Q. Substratos e temperaturas para testes de germinação e vigor de sementes de Amburana cearensis (Allemão) AC Smith. Revista Arvore, v.34, n.1, p. 57-64, 2010. http://www.scielo.br/pdf/ rarv/v34n1/v34n1a07.pdf

HALINSKI, S.; COSMO, N.L.; GOGOSZ, A.M.; REGO, S.S.; NOGUEIRA, A.C.; KUNIYOSHI, Y.S. Caracterização morfológica de frutos, sementes, plântulas e germinação de sementes de Casearia decandra. Pesquisa Florestal Brasileira, v.33, n.75, p.253-259, 2013. http://pfb.cnpf.embrapa.br/ pfb/index.php/pfb/article/view/451/324

KODAMA, M. T.; SARTORI, A. L. B. Caracterização morfológica de plântulas de Hymenaea stigonocarpa var. stigonocarpa Mart. ex Hayne, $H$. stigonocarpa Hayne var. brevipetiolata N. Mattos e H. courbaril L. Revista Brasileira de Biociências, v.5, n.1, p.663-665, 2007. http://www.ufrgs.br/ seerbio/ojs/index.php/rbb/article/view/675/565

LABORIAU, L.G. A germinação das sementes. Washington, DC: Secretaria Geral da Organização dos Estados Americanos, 1983. 174 p.

LIMA, J.D.; ALMEIDA, C.C.; DANTAS, V.A.V.; SILVA, B.M.S., MORAES, W.S. Efeito da temperatura e do substrato na germinação de sementes de Caesalpinia ferrea Mart. ex Tul. (Leguminosae, Caesalpinoideae). Revista Árvore, v.30, n.4, p.513-518, 2006. http://www.scielo.br/pdf/rarv/v30n4/31671.pdf

LIMA JUNIOR, M.J.V. (Ed.). Manual de procedimentos para análise de sementes florestais. Manaus: UFAM, 2010. 146p. http://leaonet.com/ sementesrsa/sementes/Manual\%20de $\% 20$ An $\%$ C3\%A1lise $\% 20 \mathrm{de} \% 20$ Sementes.pdf

LORENZI, H. Árvores Brasileiras: manual de identificação e cultivo de plantas arbóreas do Brasil. 3 ed. Nova Odessa: Plantarum, v.1, 2008. 368 p.
MACEDO, M.C.; SCALON, S.P.Q.; SARI, A.P.; SCALON FILHO, H.; ROSA, Y.B.C.J.; ROBAINA, A.D. Biometria de frutos e sementes e germinação de Magonia pubescens St. Hil (Sapindaceae). Revista Brasileira de Sementes, v.31, n.2, p.202-211, 2009. http://www.scielo.br/pdf/rbs/v31n2/v31n2a24.pdf

MAGUIRE, J.D. Speed of germination aid in selection and evaluation for seedling emergence and vigor. Crop Science, v.2, n.1, p.176-177, 1962.

MARCOS-FILHO, J. Fisiologia de sementes de plantas cultivadas. Piracicaba: FEALQ, 2005. 495 p.

MELO, M.G.; MENDES, A.M. S. Jatobá - Hymenaeae courbaril. Manaus: Redes de Sementes da Amazônia, 2005. 2 p. (Informativo Técnico, 9)

MONDO, V.H.V.; BRANCALION, P.H.S.; CICERO, S.M.; NOVEMBRE, A.D.L.C.; NETO, D.D. Teste de germinação de sementes de Parapiptadenia rigida (Benth.) Brenan (Fabaceae). Revista Brasileira de Sementes, v.30, n.2, p.177-183, 2008. http://www.scielo.br/pdf/rbs/v30n2/a22v30n2.pdf

NASCIMENTO, W.M. Temperatura x germinação. Seed News, v.4, n.4, p.4445, 2000. http://www.cnph.embrapa.br/public/textos/texto3.html

OLIVEIRA, L.M.; DAVIDE, A.C.; CARVALHO, M.L.M. Teste de germinação de sementes de Peltophorum dubium (Spregel) Taubert Fabaceae. Revista Floresta, v.38, n.3, p.545-551, 2008. http://ojs.c3sl.ufpr. br/ojs/index.php/floresta/article/view/12425/8543

REGO, S.S; COSMO, N.L.; GOGOSZ, A.M.; KUNIYOSHI, Y.S.; NOGUEIRA, A.C. Caracterização morfológica e germinação de sementes de Curitiba prismatica (D. Legrand) Salywon \& Landrum. Revista Brasileira de Sementes, v.33, n.4, p.616-625, 2011. http://www.scielo.br/pdf/rbs/v33n4/03.pdf

RESSEL, K.; GUILHERME, F.A.G.; SCHIAVINI, I.; OLIVEIRA, P.E. Ecologia morfofuncional de plântulas de espécies arbóreas da Estação Ecológica do Panga, Uberlândia, Minas Gerais. Revista Brasileira de Botânica, v.27, p.311-323, 2004. http://www.scielo.br/pdf/rbb/v27n2/ v27n2a10.pdf

SHANLEY, P. Jatobá: Hymenaea courbaril L. In: SHANLEY, P.; MEDINA, G. (Ed.). Frutíferas e plantas úteis na vida amazônica. Belém: CIFOR, 2005. p.105-113.

SOUZA, P.F.; OLIVEIRA, L.F.R.; SANTANA, R.C.; FERNANDES, J.S.C.; OLIVEIRA, M.L.R.; NERY, M.C.; PIRES, R.M.O. Storage of Hymenaea courbaril seeds in subzero temperature up to six months. Australian Journal of Basic and Applied Sciences, v.7, n.13, p.147-153, 2013. https://www. researchgate.net/publication/267764372_Storage_of_Hymenaea_Courbaril_ Seeds_In_Subzero_Temperature_Up_To_Six_Months 